Provided for non-commercial research and education use. Not for reproduction, distribution or commercial use.

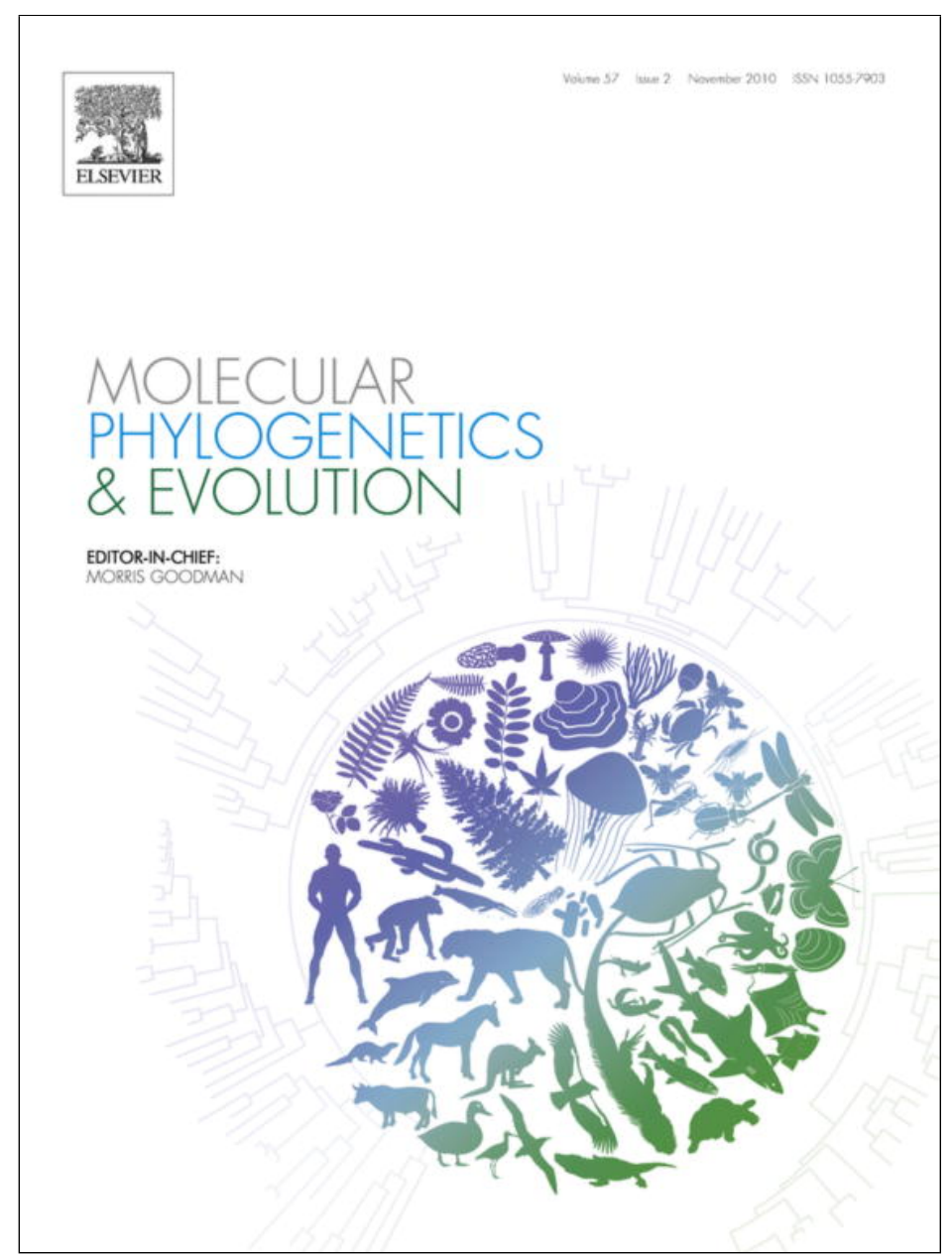

This article appeared in a journal published by Elsevier. The attached copy is furnished to the author for internal non-commercial research and education use, including for instruction at the authors institution and sharing with colleagues.

Other uses, including reproduction and distribution, or selling or licensing copies, or posting to personal, institutional or third party websites are prohibited.

In most cases authors are permitted to post their version of the article (e.g. in Word or Tex form) to their personal website or institutional repository. Authors requiring further information regarding Elsevier's archiving and manuscript policies are encouraged to visit:

http://www.elsevier.com/copyright 
Short Communication

\title{
Comparisons of the genetic structure of Squalius populations (Teleostei, Cyprinidae) from rivers with contrasting histories, drainage areas and climatic conditions based on two molecular markers
}

\author{
V. Almada, C. Sousa-Santos* \\ ISPA - Instituto Universitário, Unidade de Investigação Em Eco-Etologia, Rua Jardim do Tabaco 34, 1149-041 Lisboa, Portugal
}

\section{A R T I C L E I N F O}

\section{Article history:}

Received 15 April 2010

Revised 28 July 2010

Accepted 16 August 2010

Available online 22 August 2010

\section{Keywords:}

Cyprinidae

Mediterranean

Iberian Peninsula

Glacial refugia

Metapopulations

Freshwater fish

\begin{abstract}
A B S T R A C T
The genetic structure of Squalius populations from Portuguese Atlantic- and Mediterranean-type streams (assigned to six distinct morphoclimatic regions) was compared using sequences of the cytb and betaactin genes. The drainage area was significantly correlated to all the genetic diversity indices, pointing to the need to control for this effect in comparing populations with different histories and paleoecologies. A significant correlation was also found between genetic diversity and the morphoclimatic regions to which the rivers were assigned, with the highest diversity in warmer, lower latitude, Mediterranean-type streams. This relationship was not due to idiosyncratic characteristics of the clades compared. When the drainage area and phylogenetic effects were removed, the southern Mediterranean streams harboured significantly more genetic diversity even when compared with much larger northern streams. It is argued that these results are likely caused both by the metapopulation structure of the Mediterranean streams and by the severe reduction or local extinction of populations in the northern rivers during glaciations.

(c) 2010 Elsevier Inc. All rights reserved.
\end{abstract}

\section{Introduction}

In recent years, biologists became increasingly aware of the high level of endemism and diversity in the Mediterranean region (Myers et al., 2003) and of its role as an important European Pleistocene glacial refugium (Gómez and Lunt, 2006).

This richness is also true for freshwater fish (Reyjol et al., 2007), despite the fact that the Mediterranean rivers tend to suffer very strong seasonal fluctuations in water volume and flow regime, being drastically reduced to a series of more or less disconnected pools during the summer (Gasith and Resh, 1999). In these pools, large numbers of fish are forced to congregate, are subjected to the limited food available and exposed to extremes of temperature when water level becomes very low (Magoulick and Kobza, 2003). Moreover, the summer droughts are unpredictable in amplitude and duration and sometimes cause the complete dissection of many refugial pools.

The special habitats of the typical Mediterranean streams, and the high level of standing biodiversity and endemism of their ichthyofauna (Goméz and Lunt, 2007), combine to make conservation of these fish one of the highest priorities and, at same time, one task of particular difficulty. This difficulty is not limited to

* Corresponding author. Address: ISPA - Instituto Universitário, Unidade de Investigação em Eco-Etologia, Rua Jardim do Tabaco, 34, 1149-041 Lisboa, Portugal. Fax: +351 218860954.

E-mail address: csousasantos@gmail.com (C. Sousa-Santos). the nature of the habitat and the fish living in it, but also to the fact that small water volumes in which large fractions of populations are concentrated, are especially vulnerable to almost all kinds of pollution and environment degradation.

In this context, the conservation of freshwater fish in countries like Portugal, Spain, Italy and Greece, among others, is a priority to the conservation of European biodiversity. This condition prompted several population genetic studies on Mediterranean freshwater fish from European countries (e.g. Doadrio and Carmona, 2004; Mesquita et al., 2005, 2007).

A proper evaluation of the peculiarities of the Mediterranean fish populations requires, however, that they are contrasted with populations more to the north, occurring in more rainy climates, and that were subjected to much more severe glaciation-mediated disturbances. In undertaking this comparative approach, that often involves contrasting the phylogeography of different species, it is necessary to control first for two phylogenetic effects: (i) the differences in genetic diversity between lineages could be a mere reflection of different divergence times (older lineages may have had more time to accumulate diversity); (ii) some lineages - because of their life history, physiology, behavior, etc. - may have been prone to more rapid diversification and/or extinction than others. Moreover, ancestral polymorphisms occurring in one or more lineages may add an additional complication to the analysis.

In the Iberian Peninsula, there are at least eight species in the genus Squalius (excluding hybrid complexes), two of which are considered to be critically endangered (Cabral et al., 2005). Their 
distribution (Fig. 1) and phylogeny have been thoroughly studied and distinct studies converged in a common pattern: apart from a form (Squalius laietanus) closely related to Squalius cephalus and restricted to the river Ebro, in eastern Spain, the remaining species form a very well defined monophyletic group with more than six million years of evolutionary history inside Iberia (Brito et al., 1997; Doadrio, 2001; Doadrio and Carmona, 2003, 2006; Mesquita et al., 2005, 2007; Sanjur et al., 2003; Sousa-Santos et al., 2007).

The robustness of the Iberian Squalius phylogeny provides a very stimulating opportunity to perform comparative phylogeographical analyses in which the signatures of events in the paleoecology and demographic history of populations can be detected after controlling for the phylogeny of the species as a hole.

Squalius species occupy basins of very different sizes and subjected to very distinct climatic/hydrological conditions (Fig. 1 and Table 1): while in the South the streams are typically Mediterranean, northern rivers are in an area of Atlantic climate, with very high rainfall, and thus are colder, carry large water volumes, reach high flow velocities and do not dry out in the summer. Moreover, the northern part of the Iberian Peninsula, especially in higher altitudes, was much more severely affected by glaciations than the Mediterranean area (Petit-Marie et al., 2000) which has been demonstrated to have provided glacial refugia for a wide spectrum of taxa (Schmitt, 2007).

The diversity in hydrology and climate, both past and present, to which the populations of Squalius have been subjected, provides the opportunity to study the way the differences between northern Atlantic and southern Mediterranean conditions affected the genetic structure of the populations. As both in the North and South of Portugal, there are streams of very different areas, a comparative phylogeographical analysis of the four species of Squalius that occur in these rivers may help to assess the effects of two climatic regions in the genetic structure of populations, after controlling for the effects of the drainage area and of the phylogenetic history of the species. More specifically, we used the wealth of mitochondrial cytochrome $b(\mathrm{cyt} b)$ and nuclear beta-actin gene sequences available in the GenBank to investigate if the genetic differences expected to be found between northern and southern populations are attributable to the phylogenetic history of the species or due to distinct climates to which they have been subjected over time.

\section{Materials and methods}

A total of 501 and 336 sequences, respectively, of the cytb and beta-actin genes from four Iberian Squalius species (S. aradensis, S. carolitertii, S. pyrenaicus and S. torgalensis), from 21 independent river basins, were compiled (GenBank accession numbers in Table S1). Most of them were obtained previously by the authors (SousaSantos et al., 2005, 2006a,b, 2007). Primers and PCR conditions to obtain five new sequences are described elsewhere (Sousa-Santos et al., 2007). Sequences were aligned with CodonCode Aligner.

Phylogenetic relationships were reconstructed by maximum parsimony (MP; heuristic searches, 10 random stepwise additions and TBR branch swapping) and maximum likelihood (neighbourjoining, NJ), using PAUP 4.0. Branch support was tested by bootstrap analysis (1000 resamplings).

Molecular diversity indices $(k, \pi$, and $h)$ were estimated with Arlequin 3.01 (Excoffier et al., 2005). The hd index represented the number of distinct haplotypes divided by the number of individuals (or gene copies, in the case of calculations for the beta-actin gene sequences, to account for heterozygotes).

Corrected average pairwise distances between clades were subsequently transformed in percent sequence divergence after divisions by the length of the DNA fragment analysed.

Networks of haplotypes were performed with TCS 1.21 .

AMOVA, $F_{\mathrm{ST}}$ statistics (level of significance of $0.05,10.100$ permutations) and mismatch distributions were performed with Arlequin 3.01. This software was also used to compute the parameters of the expansion $\theta_{0}, \theta_{1}, M$ and $\tau$. Effective population sizes before $\left(N_{0}\right)$ and after $\left(N_{1}\right)$ a sudden expansion event, were calculated from $\theta_{0}$ and $\theta_{1}$ using the equation $\theta=2 \mathrm{~N} \mu$, where $\mu$ is the total mutation rate per sequence per generation. Considering the divergence rate of the cyt $b$ gene estimated by Dowling et al. (2002), a mutation rate of $12.704 \times 10^{-6}\left(0.0053 \times 10^{-6}\right.$ substitutions/lineage/year $\times 799$ sites $\times$ time of generation of 3 years) was used. The generation time was calculated as the average age of maturation retrieved from several studies on the biology of S. pyrenaicus (Fernández-Delgado and Herrera, 1994; Geraldes and Collares-Pereira, 1995), S. torgalensis (Magalhães et al., 2003) and S. carolitertii (Maia et al., 2006).

The expected mismatches under both sudden and spatial expansion scenarios were modelled assuming constant deme size

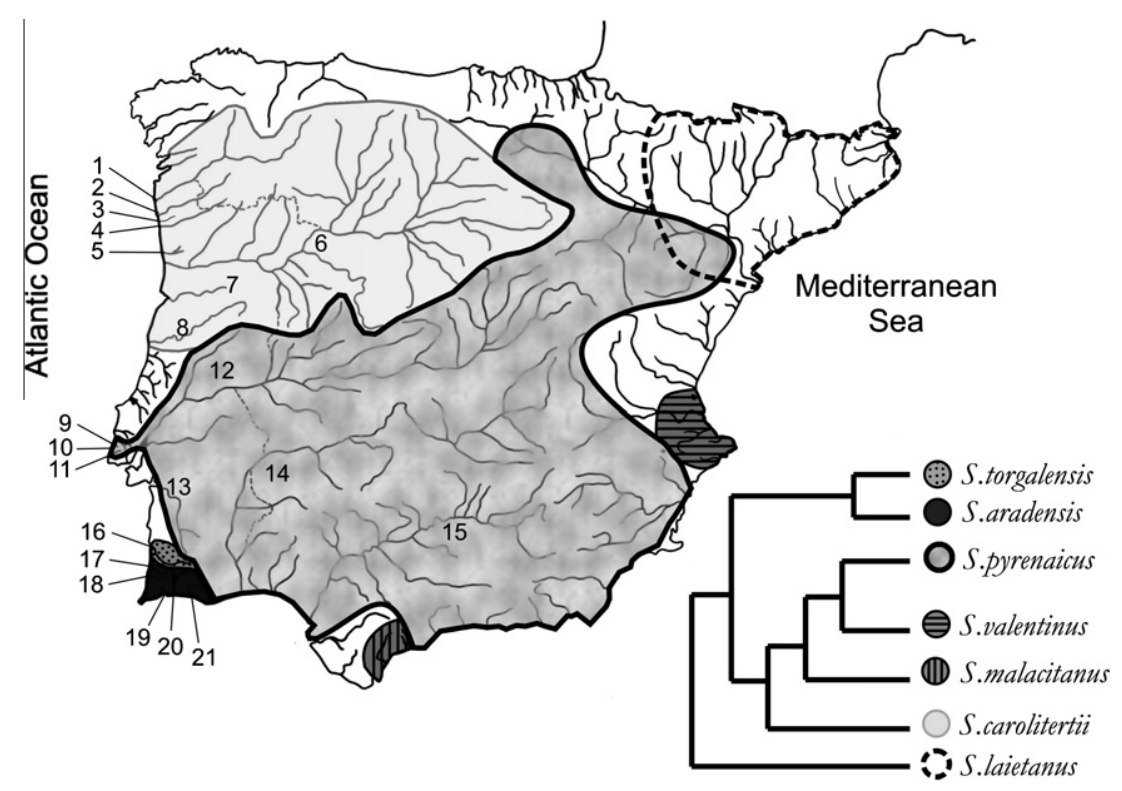

Fig. 1. Distribution of the Squalius species in the Iberian Peninsula and sampled river basins: (1) Minho, (2) Lima, (3) Neiva, (4) Cávado, (5) Ave, (6) Douro, (7) Vouga, (8) Mondego, (9) Lizandro, (10) Colares, (11) Samarra, (12) Tagus, (13) Sado, (14) Guadiana, (15) Guadalquivir, (16) Mira, (17) Seixe, (18) Aljezur, (19) Alvor, (20) Arade, (21) Quarteira. A schematic tree representing the phylogenetic relationships between the Squalius species is also depicted (adapted from Doadrio and Carmona, 2006). 


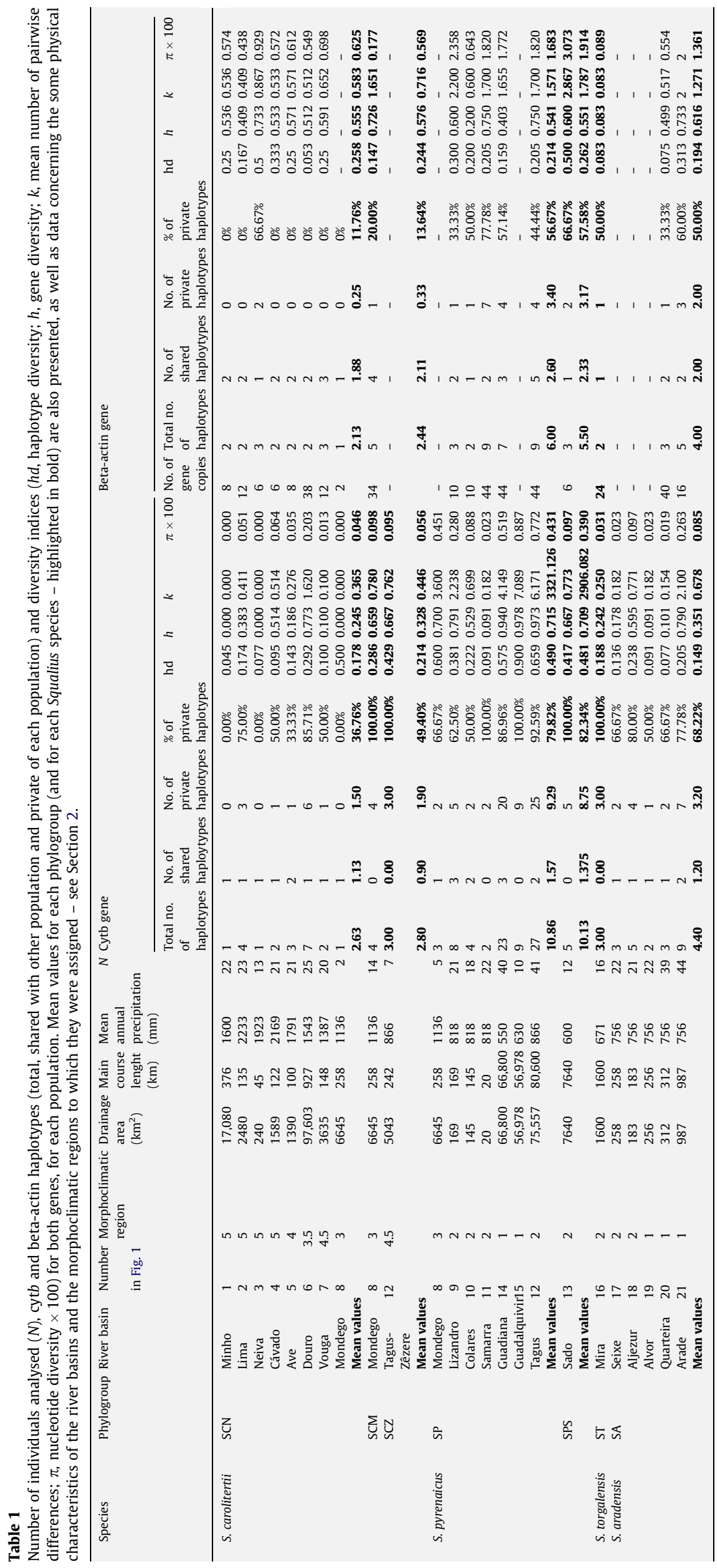


of populations. To evaluate the goodness-of-fit between the observed and model frequency distributions, the sum of squared deviations (SSD) and the Harpending's Raggedness indexes were calculated ( $p$ values based on 10,000 replicates).

Fu's Fs tests (Fu, 1997) based on 10,000 replicates were performed with Arlequin 3.01. For expanding populations, $\tau$ was used to estimate the time since the expansion $(t)$ using the equation $\tau=2 \mu t$ ( $\mu$ as defined above).

As it is well known that the diversity of a population is influenced by the area it occupies (Ricklefs, 1990), we assessed the relative contribution of the drainage area on each genetic diversity indices through simple regressions where area (log transformed - $\log$ Area) was the independent variable. Subsequently, a factor analysis was conducted using as variables the residuals of the regressions. The factor scores obtained for each population were used as a compound diversity index (CDI) that synthesized the information of all the diversity indices and its correlation with the climatic zone to which the population belonged was tested. All statistical analyses except for the phylogeographical ones were performed with Statistica 7.0.

Data concerning drainage total area and annual precipitation were retrieved from management plans established by Portuguese authorities for each basin (downloaded in Portuguese from the INAG - National Water Institute: <http://www.inag.pt/inag2004/port/ a_intervencao/planeamento/pbh/pbh.html $>$ ). River basins were classified into morphoclimatic regions following the classification defined by INAG (2008), according to the guidelines of the Water Framework Directive. This classification identified six morphoclimatic regions and recognized a north-south gradient of temperature, precipitation, altitude and flow regime for Portuguese rivers (INAG, 2008) - the lowest scores (regions 1 and 2) correspond to the hottest and driest southern Mediterranean rivers, while the highest scores (regions from 3 to 6 ) correspond to the northern rivers of the Atlantic part of Portugal, with the maximum scores at the higher altitudes in the north - Fig. S1. This north-south gradient parallels the gradient from a typical Atlantic climate prevailing in the northwest of the country to the south, where Mediterranean conditions occur. Superimposed on this general trend, altitude and local topography may also affect the classification of each drainage. It is important to note that different tributaries of a drainage are often classified by INAG (2008) in different morphoclimatic regions, the same being frequently true for different sections of the same river - Fig. S1.

The sampling points of the present study were superimposed to the map representing the morphoclimatic regions and the number of the region (numbered from 1 to 6 - Fig. S1) was attributed to the respective sampled population - Table 1 . For Douro, Vouga and Tagus (Zêzere) river basins, since the sampling points were located between two regions, an intermediate value was attributed: 3.5 for Douro and 4.5 for Vouga and Tagus (Zêzere) - Table 1. Regarding the Guadalquivir river basin, since it is located outside the Portuguese territory and no similar classification in morphoclimatic regions is known, it was assumed that its morphoclimatic region was the same as the one described for the Guadiana River, due to their geographical proximity.

\section{Results}

\subsection{Phylogenetic analysis}

For the cytb gene fragment analysed (799 bp), 268 sites were variable 193 of which were parsimony informative. For the betaactin gene (943 bp including gaps), 26 sites were variable 15 of which were parsimony informative.
The monophyly of the four Squalius species at the mtDNA level was strongly supported, as well as the recovery of two main evolutionary lineages: a southwestern lineage of $S$. aradensis and $S$. torgalensis, and a more widely distributed lineage of $S$. pyrenaicus and S. carolitertii (Fig. 2).

Within each species, the inference methods failed to resolve the relationships between haplotypes so that unresolved polytomies were found bellow the species level, with some clades emerging as well supported groups, namely the samples of $S$. pyrenaicus from the Sado River (Fig. 2).

The presence of these polytomies and lack of species differentiation for beta-actin (Fig. 2) may result from incomplete lineage sorting and the persistence of ancestral haplotypes in the populations. Thus, we explored the data with phylogeographic tools that do not involve the assumptions of dicothomous trees and extinction of ancestral haplotypes.

\subsection{Parsimony network analysis}

The parsimony network of mtDNA haplotypes allowed the identification of seven clades (Fig. S2): S. pyrenaicus (SP), S. pyrenaicusSado (SPS), S. carolitertii-North (SCN), S. carolitertii-Mondego (SCM), S. carolitertii-Zêzere (SCZ), S. aradensis (SA) and S. torgalensis (ST). All clades appear as unlinked subnetworks, except for the SCN, SCM and SCZ clades that were clustered together. Contrastingly, haplotypes from the SPS clade, traditionally assigned to S. pyrenaicus, did not cluster according to their species designation, reflecting a considerable degree of isolation from the SP clade (Fig. S2).

The SCN subnetwork showed a star-like pattern, centred on an ancestral haplotype with a high frequency (occurring in 111 out of 147 fish from the SCN clade, sampled in seven independent drainages), from which the remaining haplotypes were derived (most of them by a single mutation) - Fig. S2. SCM, SCZ, SPS and ST subnetworks also bear the characteristic pattern of a recent diversification, with one most common haplotype and only 2-3 derived ones (Fig. S2). For SA and SP subnetworks the patterns of phylogeographic structure were considerably deeper, with a large number of haplotypes derived by a variable number of steps from the ancestor (up to 22), most of which were private to particular rivers, pointing to older diversification processes centred in the Arade River for the S. aradensis radiation and at least in the Tagus and Guadiana basins for the S. pyrenaicus radiation (Fig. S2).

Clades were geographically isolated except in two points where overlapping was observed (Fig. 2): in the Zêzere River (Tagus River basin) samples belonged to SCZ and SP clades, and in the Mondego River samples belonged to SP, SCN and SCM clades.

Nuclear haplotypes were shared not only between populations of the same species but also between taxonomically distinct species (Fig. S3): S. pyrenaicus samples shared haplotypes with S. carolitertii and S. aradensis; and S. torgalensis with S. aradensis. It was also notorious that northern populations shared more haplotypes among them than do southern ones: five out of the eight haplotypes found in S. carolitertii were found in more than one population, contrasting with the six out of 18 haplotypes found in $S$. pyrenaicus populations (Fig. S3). This lack of taxonomical distinction at the nuclear level was also evident in the phylogenetic tree for the beta-actin gene (Fig. 2).

\subsection{Variation between clades}

Globally, for both genes, S. pyrenaicus showed the highest values for most of the diversity indices, and S. torgalensis, a species that is restricted to a single river basin, the lowest values (Table 1 ). S. carolitertii showed the lowest average number of haplotypes and the lowest percentage of private haplotypes for both genes (Table 1). This finding corroborates the interpretation presented above for 

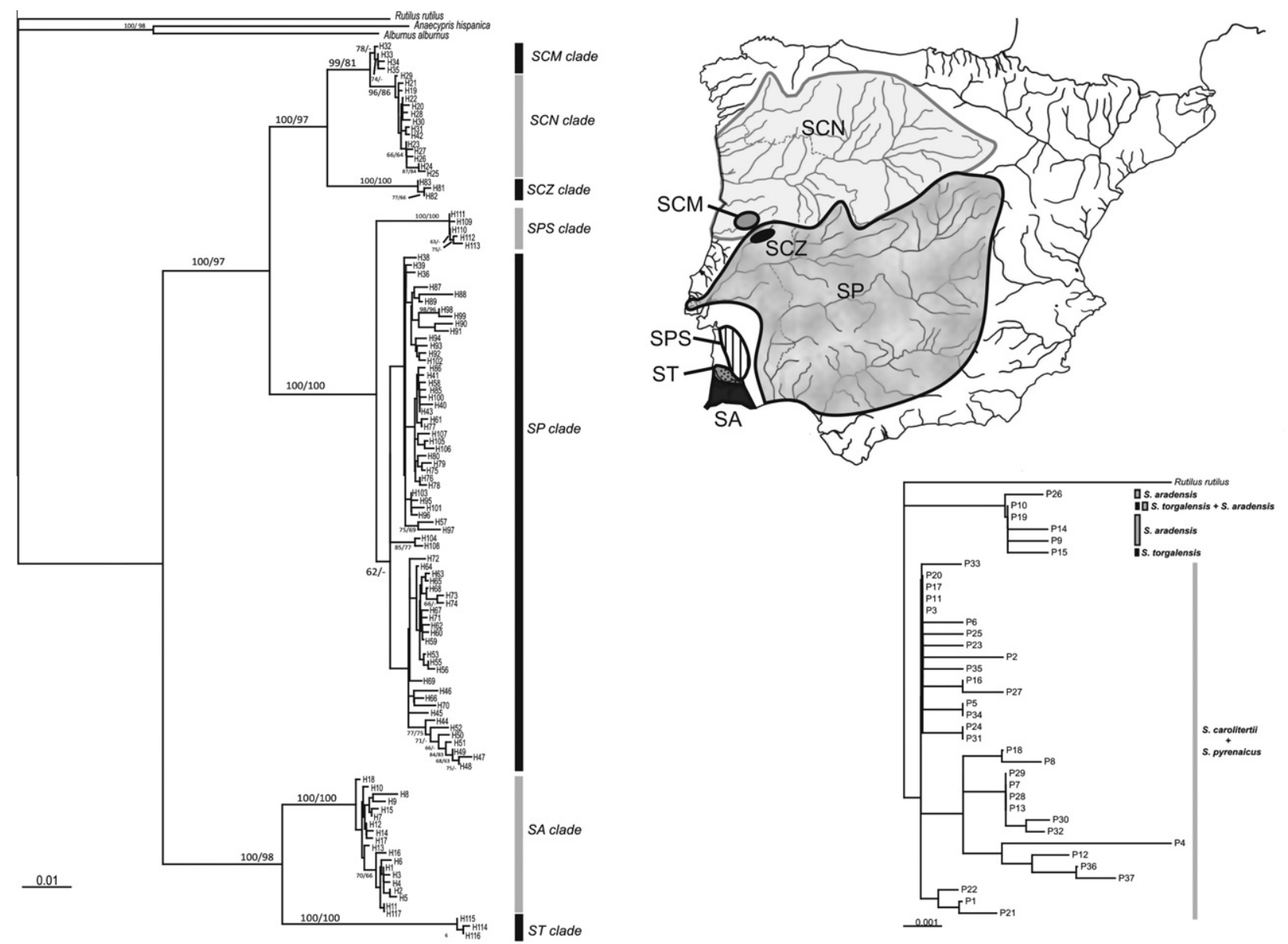

Fig. 2. Neighbour-joining tree illustrating the phylogenetic relationships among sampled Iberian Squalius, based on cytb (left) and beta-actin (right) gene sequences. Bootstrap values are indicated (NJ/MP) for each well supported node (60\% majority rule). Anaecypris hispanica, Rutilus rutilus and Alburnus alburnus were used as outgroups. The correspondence of each haplotype to individual samples may be found in Table S1. For a description of the acronyms of the cytb gene clades see the Section 3 . The geographical locations of the clades are depicted.

nuclear DNA implying that fewer private haplotypes were found in northern populations.

Considering the clades retrieved from the mtDNA analysis, the SCN clade was, among the $S$. carolitertii clades, the one with the lowest mean values for all the diversity indices; and the SCZ clade showed high mean values, comparable to the ones obtained for $S$. pyrenaicus (Table 1). Among the S. pyrenaicus clades (SP and SPS), the differences between mean values were negligible (Table 1 ). It is worth to mention, however, that the sampled individuals from Sado River (SPS clade) presented extremely high percentages of private mtDNA (100\%) and nuclear DNA (66.67\%) haplotypes (Table 1 ), which may explain the degree of isolation from the SP clade described above.

The lowest corrected inter-clade divergences (Table 2) were obtained between the three $S$. carolitertii clades ( 0.75 to 3.39\%) and between the two S. pyrenaicus clades (2.13\%). SA and ST clades showed $5.40 \%$ of divergence between them and about $8-11 \%$ of divergence from the remaining clades (Table 2 ).

After grouping the beta-actin gene sequences according to the mtDNA clades to which the corresponding sample belonged, the lowest percentages of divergence were detected between SCN, SCM, SP and SPS clades (Table 2), corroborating the view that the taxonomical distinction between S. carolitertii and S. pyrenaicus is not evident with this nuclear marker.

AMOVA showed that the mtDNA variation between Squalius species and among clades within species accounted, respectively, for $72.10 \% \quad(\mathrm{FCT}=0.721, p=0.000)$ and $22.94 \% \quad(\mathrm{FSC}=0.822$, $p=0.000$ ) of the total variation. Only $4.96 \%$ of the variation was due to differences within clades ( $F S T=0.950, p=0.000$ ). This view was supported by the pairwise $\mathrm{F}_{\mathrm{ST}}$ values that showed no signature for gene flow between clades (Table 2). Most of the nuclear DNA variation $(50.09 \%)$ was also due to variation between Squalius species $(\mathrm{FCT}=0.501, p=0.023$ ). Variation among clades within species and within clades accounted, respectively, for $20.30 \%$ (FSC $=0.407$, $p=0.000)$ and $29.62 \%(F S C=0.822, p=0.000)$ of the total nuclear DNA variation. Pairwise $F_{\mathrm{ST}}$ values showed no signature for gene flow between clades, except for the ST-SA pair (Table 2).

\subsection{Intra-clade variation}

The view that SP and SA were the most structured and diversified of all clades (Fig. S2) was corroborated by their higher intra-clade divergences: $0.84 \%$ for SP and $0.34 \%$ for SA (values for the remaining clades ranged between $0.03 \%$ and $0.10 \%$ - Table 2 ). A similar pattern was obtained for the beta-actin sequences (Table 2).

AMOVA applied independently to the three clades with more than one population showed that the majority of the mitochondrial variation was explained by variation among populations for the SA clade and within populations for the SCN clade (Table S2). For the SP clade, the percentages of variation among and within populations were similar (Table S2). At the nuclear level, most of the variation was due to differences among populations for the SP clade and within populations for the SA and SCN clades (Table S2).

Gene flow between populations of the same clade was not detected at the mitochondrial level, with the exception of some neighbouring populations of the SCN clade - Table S3. Nuclear 
Table 2

Relationships between Squalius phylogroups based on the average corrected pairwise distances between haplotypes. Diagonal: intra-phylogroup variability (cytb/beta-actin); Above diagonal: $\mathrm{F}_{\mathrm{ST}}$ statistics and their respective p values for cyt $b$ (above) and beta-actin (below); Below diagonal: inter-phylogroup percentage of divergence (cyt $b /$ beta-actin) and respective estimated time of divergence based on the divergence rates for cytb gene calculated by Dowling et al. (2002).

\begin{tabular}{|c|c|c|c|c|c|c|c|}
\hline & $\mathrm{SCN}$ & $\mathrm{SCZ}$ & SCM & SP & SPS & SA & ST \\
\hline \multirow[t]{2}{*}{ SCN } & & $0.98(p=0.000)$ & $0.91(p=0.000)$ & $0.92(p=0.000)$ & $0.99(p=0.000)$ & $0.98(p=0.000)$ & $0.99(p=0.000)$ \\
\hline & $0.08 \% / 0.06 \%$ & - & $0.41(p=0.000)$ & $0.35(p=0.000)$ & $0.75(p=0.000)$ & $0.87(p=0.000)$ & $0.89(p=0.000)$ \\
\hline \multirow[t]{2}{*}{ SCZ } & $3.39 \% /-$ & & $0.97(p=0.000)$ & $0.87(p=0.000)$ & $0.99(p=0.000)$ & $0.97(p=0.000)$ & $1.00(p=0.000)$ \\
\hline & 3.20 My & $0.10 \% /-$ & - & - & - & - & - \\
\hline \multirow[t]{2}{*}{ SCM } & $0.75 \% / 0.06 \%$ & $3.20 \% /-$ & & $0.86(p=0.000)$ & $0.98(p=0.000)$ & $0.96(p=0.000)$ & $0.99(p=0.000)$ \\
\hline & $0.71 \mathrm{My}$ & $3.02 \mathrm{My}$ & $0.10 \% / 0.17 \%$ & $0.19(p=0.000)$ & $0.54(p=0.000)$ & $0.80(p=0.000)$ & $0.79(p=0.000)$ \\
\hline \multirow[t]{2}{*}{ SP } & $5.35 \% / 0.08 \%$ & $5.51 \% /-$ & $4.77 \% / 0.06 \%$ & & $0.73(p=0.000)$ & $0.94(p=0.000)$ & $0.93(p=0.000)$ \\
\hline & $5.05 \mathrm{My}$ & $5.20 \mathrm{My}$ & $4.50 \mathrm{My}$ & $0.84 \% / 0.26 \%$ & $0.40(p=0.000)$ & $0.73(p=0.000)$ & $0.68(p=0.000)$ \\
\hline \multirow[t]{2}{*}{ SPS } & $6.22 \% / 0.08 \%$ & $6.95 \% /-$ & $5.64 \% / 0.22 \%$ & $2.13 \% / 0.17 \%$ & & $0.97(p=0.000)$ & $0.99(p=0.000)$ \\
\hline & $5.87 \mathrm{My}$ & $6.55 \mathrm{My}$ & $5.32 \mathrm{My}$ & $2.01 \mathrm{My}$ & $0.10 \% / 0.30 \%$ & $0.82(p=0.000)$ & $0.82(p=0.000)$ \\
\hline \multirow[t]{2}{*}{ SA } & $8.56 \% / 0.45 \%$ & $9.61 \% /-$ & $8.58 \% / 0.47 \%$ & $8.63 \% / 0.48 \%$ & $9.77 \% / 0.46 \%$ & & $0.95(p=0.000)$ \\
\hline & $8.08 \mathrm{My}$ & $9.07 \mathrm{My}$ & 8.09 My & $8.14 \mathrm{My}$ & $9.21 \mathrm{My}$ & 0.34\%/0.09\% & $0.10(p=0.050)$ \\
\hline \multirow[t]{2}{*}{ ST } & $9.84 \% / 0.45 \%$ & $10.56 \% /-$ & $9.35 \% / 0.46 \%$ & $10.79 \% / 0.48 \%$ & $11.72 \% / 0.47 \%$ & $5.40 \% / 0.01 \%$ & \\
\hline & $9.28 \mathrm{My}$ & 9.96 My & $8.82 \mathrm{My}$ & 10.18 My & 11.05 My & $5.09 \mathrm{My}$ & $0.03 \% / 0.02 \%$ \\
\hline
\end{tabular}

gene flow was detected between almost all SCN populations, and between four populations within the SP clade (Table S3).

The width of the mismatch distributions for pooled mtDNA data of each Squalius clade (which may be taken as a measure of the depth of the clade genealogy) was considerably larger for SP, moderate for SA, and narrower for SCN, SPS and ST (Fig. S4). For the SCZ and SCM clades the least square procedure to fit model mismatch distribution and observed distribution did not converge after 1800 steps. Mismatch distributions were bimodal for SA and SP and unimodal for the SCN, SPS and ST clades (Fig. S4).

A signature for expansion was detected for SPS, SP, SCN and ST clades ( $p<0.02$, Fu's tests) - Table 2 . A sudden expansion was estimated to have occurred in the Holocene and Pleistocene, respectively, for the SPS and ST clades after a founder event and/or a severe bottleneck $\left(N_{0}=0\right)$ (Table 2$)$. A Holocenic spatial expansion was estimated to have occurred for the SCN and SP clades, with a higher exchanging rate of migrants for the SP clade (Table 2).

\subsection{Influence of climate and hydrology}

The hypothesized influence of hydrology and climate was only tested for the structured mtDNA data. To represent the Mondego basin, only the sequences belonging to the SCM clade were considered since the remaining clades were less represented in this population and may be a result of introgressions.

Simple regression analyses showed that each diversity index is significantly correlated with the drainage area (data not shown). Factor analyses using the residuals of regressions of each diversity index and $\log$ Area as variables showed that a single factor explained $85.52 \%$ of the variance. The genetic diversity (traduced by the CDI - Table S4) was significantly correlated with the morphoclimatic regions to which populations belonged (Spearman $R=0.64, p<0.05$ ). The ordination of the CDI mean values calculated for each clade showed that the lowest value $(-0.922)$ belonged to the SCN clade, which occurs in rivers with the lowest mean annual temperatures and higher average altitude, rainfall, flow and latitude (INAG, 2008). By contrast, the SP clade, showing the highest mean value $(\mathrm{CDI}=1.224)$, occurs in lower latitude rivers exhibiting higher mean annual temperatures, and lower average altitude, rainfall and flow. The CDI mean values for SA, SCM, SPS and ST clades occupied an intermediate position $(0.072$, $-0.108,-0.228,-0.264$ and -0.650 , respectively).

\section{Discussion}

Assuming that the ancestral clade is the most common, the one with more lineages arising from it, and the one that occupies a core position in the parsimony haplotype networks, the results showed that the diversity of the genus Squalius seems to have radiated from haplotypes that are presently found in S. pyrenaicus.

The present study confirmed the findings of previous authors (Sanjur et al., 2003; Doadrio and Carmona, 2006; Mesquita et al., 2007) regarding the monophyly of the four Squalius species analysed and the recovery of the two main evolutionary lineages: a southwestern lineage of $S$. aradensis and S. torgalensis, and a more widely distributed lineage of $S$. pyrenaicus and $S$. carolitertii. In addition, it was also possible, for the first time, to recover distinct clades within S. carolitertii and S. pyrenaicus.

Within S. pyrenaicus, a clade confined to the Sado River was identified (SPS clade). The presence of distinctive mtDNA and beta-actin haplotypes and geographical isolation recommends its management as an Evolutionary Significant Unit (ESU) and eventually the description of a new species as proposed by Sousa-Santos et al. (2007).

Concerning S. carolitertii, three clades were recovered, with basal relationships unresolved: SCN clade in the northern rivers, and SCM and SCZ clades in the Mondego and Zêzere Rivers, respectively. Because SCN and SCM clades are found in sympatry in the Mondego River, only nuclear markers will allow the assessment of their level of gene flow and it is thus premature to ascribe them a conservation status. Our findings indicate, however, that the highly diversified Mondego population justifies that further studies are undertaken to provide adequate conservation.

The same arguments apply to the SCZ clade - although the clade is confined to the river Zêzere, it is sympatric with S. pyrenaicus, and the level of gene flow in unknown.

The failure of the phylogenetic inference methods to resolve the intraespecific polytomies recommends some caution in interpreting our results. Indeed, the use of more samples and more markers, namely rapid evolving nuclear ones, may in the future provide well resolved trees. However, the lack of phylogenetic resolution is not necessarily caused by insufficient sampling and/or insufficient or inadequate markers. The obvious lack of lineage sorting among species in the beta-actin gene and the sharp differences in diversity between sister species may indicate that the assumptions required for a proper phylogenetic resolution are not met by these Squalius species and the clades identified by the parsimony networks may be useful starting points for further analyses.

After controlling for the positive relationship between area and genetic diversity, populations from the southern Mediterranean rivers are clearly more diverse than the ones from rivers of the northwest of the Iberian Peninsula.

The oldest divergence among Iberian Squalius involves the split of the branches leading to S. torgalensis (ST clade) and S. aradensis 
(SA clade) from the one leading to S. pyrenaicus (SP and SPS clades) and S. carolitertii (SCN, SCM and SCZ clades), corresponding to 8.08-11.05 Mya (Table 2). In spite of this, the variation in genetic diversity does not follow this branch pattern. Indeed, SA vs. ST and SCN/SCZ/SCM $v$ s. SP/SPS showed the shortest inter-clade divergence time, while at the same time showing the greatest difference in genetic diversity (Table 2). Thus, the available evidence points to the existence of historical or paleoecological factors in the evolution of SP/SPS and SCN clades that caused the sharp contrast in their genetic diversity, in spite of their recent divergence (5.055.87 Mya - Table 2).

Even relatively small southern rivers like Mira and Arade, show a level of mtDNA diversity much higher than those found in large northern rivers, corroborating the view that the southernmost part of Iberia must have simultaneously acted as a glacial refugium and a hotspot for biodiversity. These features are likely the result of the interplay between the hydrogeomorphological history of the southern streams, involving river captures, connections between headwaters and allopatric speciation events caused by marine transgressions; and the past and present-day climate conditions (regarding temperature and precipitation) which imposed several bottlenecks that most likely promoted diversification. This finding is in agreement with the results obtained for other Iberian southern species: the diversification of Barbus sclateri was Pleistocenic and glaciation cycles seem to have interacted with the geomorphology on promoting its diversification (Gante et al., 2009); and the differentiation of $S$. aradensis populations occurred by several allopatric fragmentation events during the last 800,000 years (Mesquita et al., 2005).

S. pyrenaicus proved to be the most diversified Iberian Squalius species. The high level of genetic biodiversity found in S. pyrenaicus and in the critically endangered species $S$. aradensis means that, despite the likelihood of frequent bottlenecks and reduction of streams to pools during draughts, the Mediterranean conditions are not incompatible with the maintenance of a level of diversity that is unexpectedly high.

The considerably lower diversity of $S$. torgalensis when compared to that of its sister species $S$. aradensis may be a result of bottlenecks caused by transgressions or of a low number of colonizers (Sousa-Santos et al., 2007). The former hypothesis seems to be more plausible since the marine transgressive maximum in the River Mira was reached about 5800 years ago and a marked deceleration in the rate of the sea level rise occurred from that time onwards (Alday et al., 2006), which is congruent with the Holocenic spatial expansion event postulated for the Mira population.

The differentiation, within S. pyrenaicus, of the Sado clade (SPS) must have been driven by the succession of distinct paleoenvironments in this river basin: the Sado area was constantly subjected to transgressions causing an intermittent regime of contact with the adjacent Tagus drainage until the Pleistocene (Andeweg, 2002), which is consistent with the estimated fast sudden expansion in the Holocene, subsequent to a founder event and/or a severe bottleneck.

The three clades of $S$. carolitertii seem to have had distinct histories. The clades from Mondego (SCM) and Zêzere (SCZ) are substantially more diverse than the clade that occurs in the northern rivers (SCN). This may seem surprising at the first sight since both Mondego and Zêzere rivers have their headwaters in the highest Portuguese mountain chain (Estrela Mountains) with an altitude around 2000 meters, and a well documented record of glaciation (Vieira and Ferreira, 1998). Both Mondego and Zêzere, however, flow to coastal plains of very high altitude located in Central Portugal. The retention of a higher level of diversity in these clades, when compared to the diversity found for the SCN clade, and their confinement to well defined geographical areas point to the view that these populations persisted in the rivers where they presently occur and were less severely affected by climatic oscillations than northern populations. The geographical positioning of the Mondego River in vicinity of several Tagus tributaries with which allele exchanges may have been possible (directly or via crosses with the hybridogenetic complex S. alburnoides) may also explain the presence of S. pyrenaicus haplotypes in this river drainage (Sousa-Santos et al., 2007).

Populations belonging to the SCN clade must have suffered severe glaciation-mediated bottlenecks in the Pleistocene. Even large rivers like Douro and Minho, are much lower diverse than most southern rivers of very small size (Table 1 ). It is possible that in many small northern rivers the populations were extirpated by the glaciations. Indeed, at the last glacial maximum, the Atlantic waters around north Portugal were subpolar with very low winter temperatures and there is evidence of the presence of Tundra and Taiga conditions much to the south of this area (Petit-Marie et al., 2000). In such conditions, extinctions in rivers fed by the water coming from the mountains would be very likely.

The confluence in the last glacial cycle of the rivers between Douro and Minho in a now submerged drainage (Dias et al., 2000), would have allowed recolonization from less affected basins like the Douro, in the short time before sea level rose to levels similar to the present ones. This historical scenario is consistent with many lines of evidence: (1) the extremely low diversity found in the northwest rivers; (2) the Holocenic spatial expansion event postulated for the SCN clade; (3) the widespread distribution (in seven independent rivers) of the ancestral haplotype; (4) the narrower mismatch distributions; (5) the signature for recent gene flow between the northern rivers Minho, Lima, Neiva, Ave and Vouga; and (6) the present northern limits of cyprinids in the Iberian Peninsula. Indeed, the barbel Barbus bocagei has its northern limit in the Lima River (Cabral et al., 2005), whilst the remaining species have limits in Northwest Spain, between Minho and the Bay of Biscay (Doadrio, 2001), thus cyprinids are probably still too recent in the Northwest to have colonized all available habitats.

The present results show not only high levels of genetic diversity but also the persistence of older lineages in Mediterranean streams where glaciations probably had minimal effects. We suggest that considering the fish populations of these Mediterranean streams as metapopulations (Avise, 2000) helps to solve this apparent puzzle when combined with the stochasticity of the climatic and hydrological conditions. Mediterranean streams are typically reduced to disconnected pools during the summer and, except in the smallest streams, fish will congregate in many different pools instead of a single one. Even if they bread in the vicinity of their summer refugia, (Squalius are supposed to be rather sedentary fish - Rodrigues, 1999), they will experience only local inbreeding. Drift and inbreeding in these local demes, may cause a reduction of diversity in each pool. However, the alleles that will be led to extinction or to fixation will vary from pool to pool if they are affected randomly. Thus, the overall fragmentation of populations will tend to increase different alleles in different demes, a scenario highly discussed by Avise (2000). As a consequence, these periodic fragmentations will tend to favour the retention of a high number of haplotypes, as the stochastic effects of drift will affect differently the structure of the subpopulations of each pool, slowing down the process of lineage sorting. If one remembers that these demes are probably unstable as floods and fluctuations change the topography of the river, that juveniles tend to be produced in the spring (Doadrio, 2001) before the summer aggregations are formed, and that during Winter large floods often occur likely mixing fish from many different pools, it becomes apparent that the summer aggregations are not necessarily responsible for a reduction in genetic diversity in the Mediterranean-type streams. An additional argument favouring this interpretation is the occurrence of populations with deeper mismatch distributions 
and higher percentages of exclusive haplotypes in the south, indicating that they are often much older than in the north.

Also, as advocated by some authors (Gillooly et al., 2005), the overall rate of genotypic change may be promoted by temperature: most mutations are caused by genetic damage from the byproducts of metabolism or by errors in DNA replication during cell division, processes that are both enhanced by temperature. This hypothesis would explain the higher levels of genetic diversity and endemisms in the southern streams when compared with the northern cold water streams. Indeed, southern areas support most of the current genetic variation (Taberlet et al., 1998) and thus management and conservation plans are highly desirable. This study also highlights the need to integrate ecological and historical factors in studies aimed to understand the origin and maintenance of genetic diversity.

\section{Acknowledgments}

This study was funded by the FCT Pluriannual Program (UIandD 331/94, partially FEDER funded). C. Sousa-Santos was supported by a Post-doctoral grant from FCT (SFRH/BPD/29774/2006).

\section{Appendix A. Supplementary data}

Supplementary data associated with this article can be found, in the online version, at doi:10.1016/j.ympev.2010.08.015.

\section{References}

Alday, M., Cearreta, A., Cachão, M., Freitas, M.C., Andrade, C., Gama, C., 2006. Micropaleontological record of Holocene estuarine and marine stages in the Corgo do Porto rivulet (Mira Rive3r, SW Portugal). Estuar. Coast. Shelf Sci. 66, $532-543$.

Andeweg, B., 2002. Cenozoic tectonic evolution of the Iberian Peninsula, causes and effects of changing stress fields. Ph.D Thesis. Vrije Universiteit Amsterdam, Amsterdam.

Avise, J.C., 2000. Phylogeography: The History and Formation of Species. Harvard University Press, Cambridge.

Brito, R.M., Briolay, J., Galtier, N., Bouvet, Y., Coelho, M.M., 1997. Phylogenetic relationships within genus Leuciscus (Pisces, Cyprinidae) in Portuguese freshwaters, based on mitochondrial cytochrome $b$ sequences. Mol. Phylogenet. Evol. 8, 435-442.

Cabral, M.J., Almeida, J., Almeida, P.R., Dellinger, T., Ferrand, N., Oliveira, M.E., Palmeirim, J.M., Queiroz, A.I., Rogado, L., Santos-Reis, M. (Eds.), 2005. Livro Vermelho dos Vertebrados de Portugal. Instituto da Conservação da Natureza, Lisboa.

Dias, J.M.A., Boski, T., Rodrigues, A., Magalhães, F., 2000. Coast line evolution in Portugal since the last glacial maximum until present - a synthesis. Mar. Geol. $170,177-186$.

Doadrio, I., 2001. Atlas y Libro Rojo de Los Peces Continentales de España. Ministerio Medio Ambiente - CSIC, Madrid.

Doadrio, I., Carmona, J.A., 2003. Testing freshwater Lago mare dispersal theory on the phylogeny relationships of Iberian cyprinid genera Chondrostoma and Squalius (Cypriniformes, Cyprinidae). Graellsia 59, 457-473.

Doadrio, I., Carmona, J.A., 2004. Phylogenetic relationships and biogeography of the genus Chondrostoma inferred from mitochondrial DNA sequences. Mol. Phylogenet. Evol. 33, 802-815.

Doadrio, I., Carmona, J.A., 2006. Phylogenetic overview of the genus Squalius (Actinopterygii, Cyprinidae) in the Iberian Peninsula, with description of two new species. Cybium 30, 199-214

Dowling, T., Tibbets, C.A., Minckley, W.L., Smith, G.R., 2002. Evolutionary relationships of the Plagopterins (Teleostei: Cyprinidae) from cytochrome $b$ sequences. Copeia 2002 (3), 665-678.

Excoffier, L., Laval, G., Schneider, S., 2005. Arlequin ver. 3.0: an integrated software package for population genetics data analysis. Evol. Bioinf. Online 1, 47-50.

Fernández-Delgado, C., Herrera, M., 1994. Population structure, growth and reproduction of Tropidophoxinellus alburnoides (Stendachner, 1866) in an intermittent stream of the Guadalquivir river basin (southern Spain). Arch. Hydrobiol. 130, 359-369.

Fu, Y.X., 1997. Statistical tests of neutrality of mutations against population growth, hitchhiking and background selection. Genetics 147, 915-925.
Gante, H., Micael, J., Oliva-Paterna, F.J., Doadrio, I., Dowling, T.E., Alves, M.J., 2009. Diversification within glacial refugia: tempo and mode of evolution of the polytypic fish Barbus sclateri. Mol. Ecol. 18, 3240-3255.

Gasith, A., Resh, V.H., 1999. Streams in Mediterranean climate regions: abiotic influences and biotic responses to predictable seasonal events. Annu. Rev. Ecol. Syst. 30, 51-81.

Geraldes, A.M., Collares-Pereira, M.J., 1995. Preliminary insight into age and growth of the Iberian chub (Leuciscus pyrenaicus) in the Sorraia system. Folia Zool. 44, 159-165.

Gillooly, J.F., Allen, A.P., West, G.B., Brown, J.H., 2005. The rate of DNA evolution: effects of body size and temperature on the molecular clock. PNAS 102, 140145.

Goméz, A., Lunt, D.H., 2007. Refugia within refugia: patterns of phylogeographic concordance in the Iberian Peninsula. In: Weiss, S., Ferrand, N. (Eds.), Phylogeography of Southern European Refugia. Springer, Netherlands, pp. 155-188.

INAG, 2008. Tipologia dos rios em Portugal continental no âmbito da implementação da Directiva Quadro da Âgua. I - Caracterização biótica. Ministério do Ambiente, do Ordenamento do Teritório e do Desenvolvimento Regional, Instituto da Água, Lisboa (in portuguese). Downloaded from: <http:// dqa.inag.pt/dqa2002/port/docs_apoio/doc_nac/Manuais/ Caracterizacao_rios.pdf $>$.

Magalhães, M.F., Schlosser, I.J., Collares-Pereira, M.J., 2003. The role of life history in the relationship between population dynamics and environmental variability two Mediterranean stream fishes. J. Fish Biol. 63, 300-317.

Magoulick, D.D., Kobza, R.M., 2003. The role of refugia for fishes during drought: a review and synthesis. Freshwater Biol. 48, 1186-1198.

Maia, H.M.S., Maia, C.F.Q., Pires, D.F.C., Valente, A.C.N., 2006. Biology of the Iberian chub (Squalius carolitertii) in an atlantic-type stream (river Lima basin-north Portugal). A preliminary approach. Limnetica 25, 713-722.

Mesquita, N., Cunha, C., Carvalho, G.R., Coelho, M.M., 2007. Comparative phylogeography of endemic cyprinids in the south-west Iberian Peninsula: evidence for a new ichthyogeographic area. J. Fish Biol. 71 (Supplement A), 4575.

Mesquita, N., Hänfling, B., Carvalho, G.R., Coelho, M.M., 2005. Phylogeography of the cyprinid Squalius aradensis and implications for conservation of the endemic freshwater fauna of southern Portugal. Mol. Ecol. 14, 1939-1954.

Myers, N., Mittermeier, R.A., Mittermeier, C.G., Fonseca, G.A.B., Kent, J., 2003. Biodiversity hotspots for conservation priorities. Nature 403, 853-858.

Petit-Marie, N., Bouysse, P., de Beaulieu, J.L., Boulton, G., Kershaw, P., Litsitsyna, O., Partrige, T., Pflaumannn, U., Schultz, H., Soons, J., Van Vliet-Lanoe, B., Zhengtang, G., 2000. Geological records of the recent past: a key to the near future world environments. Episodes 23, 230-246.

Reyjol, Y., Hugueny, B., Pont, D., Bianco, P.G., Beier, U., Caiola, N., Casals, F., Cowx, I., Economou, A., Ferreira, T., Haidvogl, G., Noble, R., de Sostoa, A., Vigneron, T., Virbickas, T., 2007. Patterns in species richness and endemism of European freshwater fish. Global Ecol. Biogeograph. 16, 65-75.

Ricklefs, R.E., 1990. Ecology. WH Freeman and Company, New York.

Rodrigues, J.A., 1999. Aspectos da bio-ecologia das populações de Leuciscus pyrenaicus Günther, 1868 (Pisces, Cyprinidae) na Bacia Hidrográfica do rio Tejo. Ph.D thesis, University of Lisbon.

Sanjur, O.I., Carmona, J.A., Doadrio, I., 2003. Evolutionary and biogeographical patterns within Iberian populations of the genus Squalius inferred from molecular data. Mol. Phylogenet. Evol. 29, 20-30.

Schmitt, T., 2007. Molecular biogeography of Europe: pleistocene cycles and postglacial trends. Front. Zool. 4, 11-23.

Sousa-Santos, C., Collares-Pereira, M.J., Almada, V.C., 2006a. Evidence of extensive mitochondrial introgression with nearly complete substitution of the typical Squalius pyrenaicus-like mtDNA of the Squalius alburnoides complex (Cyprinidae) in an independent Iberian drainage. J. Fish Biol. 68 (Supplement B), 292-301.

Sousa-Santos, C., Collares-Pereira, M.J., Almada, V.C., 2006b. May a hybridogenetic complex regenerate the nuclear genome of both sexes of a missing ancestor? first evidence on the occurrence of a nuclear nonhybrid Squalius alburnoides (Cyprinidae) female based on DNA sequencing. J. Nat. Hist. 40, 1443-1448.

Sousa-Santos, C., Collares-Pereira, M.J., Almada, V.C., 2007. Reading the history of a hybrid fish complex from its molecular record. Mol. Phylogenet. Evol. 45, 981996.

Sousa-Santos, C., Robalo, J., Collares-Pereira, M.J., Almada, V.C., 2005. Heterozygous indels as useful tools in the reconstruction of DNA sequences and in the assessment of ploidy level and genomic composition of hybrid organisms. DNA Seq. 16, 462-467.

Taberlet, P., Fumagalli, L., Wust-Saucy, A.-G., Cosson, J.-F., 1998. Comparative phylogeography and postglacial colonization routes in Europe. Mol. Ecol. 7, 453-464.

Vieira, G.T., Ferreira, A.B., 1998. General characteristics of the glacial geomorphology of the Serra da Estrela. In: Vieira, G.T. (Ed.), Glacial and Periglacial Geomorphology of the Serra da Estrela. Guidebook for the field-trip. IGU Commission on Climate Change and Periglacial Environments, 26-28 August 1998. CEG and Department of Geography, University of Lisbon, pp. 3748. 